\title{
Neurotransmitter regulation of neural development: acetylcholine and nicotinic receptors
}

\author{
ANDRÉA S. TORRÃO and LUIZ R.G. BRITTO \\ Departamento de Fisiologia e Biofísica, Instituto de Ciências Biomédicas \\ Universidade de São Paulo, 05508-900 São Paulo, SP, Brazil \\ Manuscript received on January 29, 2002; accepted for publication on February 11, 2002; \\ contributed by LUIz R.G. BRITTO*
}

\begin{abstract}
Several neurotransmitter systems have been related to developmental processes during the past decade. In this review, we discuss the evidence that the nicotinic acetylcholine receptors could have an additional function during development that may be unrelated to their role in cholinergic neurotransmission in the vertebrate brain. Both temporal expression data and in vitro and in vivo studies with nicotinic agonists and antagonists have provided direct support for a role of nicotinic receptors in neural developmental processes such as neurite outgrowth and differentiation. A similar picture has emerged for other neurotransmitter and receptor systems as well, which generates a new view of neural processes during both development and mature life.
\end{abstract}

Key words: acetylcholine, development, neurotransmitters, nicotine, nicotinic receptors.

\section{INTRODUCTION}

Considerable progress has been obtained in understanding the processes that control the development of the nervous system. Notable advances have been mainly generated by molecular biological approaches, which revealed several key aspects of neural development, including the determination of cell identities, target reaching, and synaptogenesis (Francis and Landis 1999, Hatten 1999). Many genes and molecules have been related to specific developmental processes. Among the recently studied developmentally-related molecules are those that control the specification and differentiation of nervous system subdivisions, such as the homeobox, engrailed, wnt and pax gene products (Joyner 1996,

Correspondence to: Luiz R.G. Britto

E-mail: 1rbritto@usp.br

*Member of Academia Brasileira de Ciências
Maconochie et al. 1996), those that regulate neurite outgrowth and axon targeting, such as gangliosides, ephrins, semaphorins, and SNARE proteins (Flanagan and Vanderhaegen 1998, Mueller 1999, O’Leary and Wilkinson 1999, Hepp and Langley 2001, Mendez-Otero and Santiago 2001), and those that regulate neuron survival and plasticity, such as the neurotrophins (Reichardt and Fariñas 1997, Shatz 1997, Huang and Reichardt 2001).

During the past decade another group of molecules has been clearly related to developmental regulation, namely the neurotransmitters and their receptors. This previously unsuspected role of the neurotransmitter systems has been revealed by experiments using in vitro preparations of several neuronal tissues and showed that neurotransmitters such as serotonin, dopamine, glutamate and acetylcholine were able to promote or block neurite outgrowth, de- 
pending on the neuronal group and the neurotransmitter involved (for review see Lipton and Kater 1989). For example, an inhibition of growth cone motility in cultured retinal neurons was observed after dopamine treatment and this effect was thought to depend on the D1-type dopamine receptor (Lankford et al. 1988). At about the same time, the Nmethyl-D-aspartate-type glutamate receptors have been unequivocally linked to the precise patterning of connections during nervous system development (Constantine-Paton et al. 1990, Shatz 1990, Simon et al. 1992). These plasticity events, namely neurite sprouting, establishment of neuronal connections, and exclusion of connections, profoundly affect the general organization of the developing and the mature nervous system. There is now consensus that those neurotransmitter systems, together with the gamma-amino-butyric acid (Billinton et al. 2001) and the nitrinergic (Contestabile 2000) systems, are all involved in some aspect of neural development, in addition to their well-known role in neurotransmission. In this review we focus on the possible involvement of nicotinic acetylcholine receptors (nAChRs) in developmental processes such as neurite outgrowth and differentiation.

\section{THE NICOTINIC RECEPTORS}

The nAChRs are members of the neurotransmittergated superfamily of ion channels and are all formed by combinations of five subunits organized around a central ion channel. The structure of nAChRs have actually provided the model for understanding of the organization of neurotransmitter-gated ion channel receptors (Lindstrom 1998). In the nervous system, twelve distinct $\mathrm{nAChR}$ subunits have been cloned and identified as $\alpha(\alpha 2-\alpha 10)$ and $\beta(\beta 2-\beta 4)$ subunits, which may constitute heteromeric or homomeric receptors. The distinct combinations of nAChR subunits produce receptors with different physiological properties and both $\alpha$ and $\beta$ subunits seem to contribute to the functional diversity of the nAChRs.

At least two branches of nAChRs may be defined based mainly on their affinity for the snake venom $\alpha$-bungarotoxin $(\alpha$-Bgt), which are the $\alpha$ Bgt-sensitive and $\alpha$-Bgt-insensitive nAChRs. The major brain subtype with high affinity for nicotine seems to be the $\alpha 4 \beta 2 \mathrm{nAChR}$ (Flores et al. 1992), which is $\alpha$-Bgt-insensitive. The major ganglionic subtype is $\alpha 3 \beta 4$ and the major subtype with high affinity for $\alpha$-Bgt found in brain and ganglia is composed of homomeric arrangements of $\alpha 7$ (Del Toro et al. 1994). The $\alpha$-Bgt-sensitive nAChRs, especially the $\alpha 7$-containing subtype, have been the target of intense investigation as they show high calcium permeability (Vijayaraghavan et al. 1992, Séguéla et al. 1993, Rathouz et al. 1996). Calcium entering the neuron through $\alpha 7$ channels could then act as a second messenger in several cellular processes, such as the regulation of neurite outgrowth and therefore of developmental and plasticity processes (Quik 1995).

The expression of nAChR subunit genes in Xenopus oocytes provided a great deal of information about the organization and function of those receptors, but it was necessary to verify if functional combinations obtained in vitro resembled the subtypes expressed in the nervous system. Ligands, antibodies and RNA probes have all been employed for the localization and quantification of the neuronal nAChRs. For example, the localization of the $\mathrm{nAChRs}$ have been investigated in vertebrate brains with ligands (Clarke et al. 1985, Sorenson and Chiappinelli 1992), immunohistochemistry to detect the nAChR proteins (Sargent et al. 1989, HamassakiBritto et al. 1991, Britto et al. 1992a,b, Torrão et al. 1997) and in situ hybridization to detect the corresponding mRNAs (Goldman et al. 1986, 1987, Boulter et al. 1987, Duvoisin et al. 1989, Wada et al. 1989, 1990, Morris et al. 1990, Dineley-Miller and Patrick 1992, Séguéla et al. 1993, Lohmann et al. 2000).

All these studies converged to reveal that the nAChRs are widely distributed throughout the mature nervous system. The next obvious step was to analyze the expression of different $\mathrm{nAChR}$ subunits during development of the nervous system. 


\section{nAChR EXPRESSION DURING DEVELOPMENT}

Several studies have shown an early expression of nAChRs and of the cholinergic system enzymes, acetylcholinesterase (AChE) and choline acetyltransferase (ChAT) in the central and peripheral nervous system of vertebrates (see Role and Berg 1996, Torrão et al. 2000). These studies employed either in situ hybridization, immunohistochemistry, immunoblotting, and binding assays, and all these techniques have revealed that the subunits which form the nAChRs are expressed very precociously. Moreover, the observation of different temporal patterns of $\mathrm{nAChR}$ expression was another strong indication of the presumptive participation of nAChRs in developmental processes (Daubas et al. 1990, Matter et al. 1990, Zoli et al. 1995, Conroy and Berg 1998, Hellstrom-Lindahl et al. 1998, Kaneko et al. 1998, Torrão et al. 2000). The study by Conroy and Berg (1998) shows, for example, an increased expression of $\alpha 5, \alpha 8$, and $\beta 2 \mathrm{nAChR}$ subunits between embryonic day 8 [E8] and E17/18 in the chick brain. Similar patterns are observed in the rat brain (Zoli et al. 1995). Transient expression is another pattern observed for several nAChR subunits. This pattern was detected in our laboratory for several subunits in the chick cerebellum (Fig. 1). The $\alpha 2, \alpha 5, \alpha 7, \alpha 8$, and $\beta 2 \mathrm{nAChR}$ subunits all begin to be expressed relatively late (at E12), show a peak of expression at E16, and are expressed at very low levels or not expressed at all in the postnatal chick (Kaneko et al. 1998, Torrão et al. 2000). Very early expression of nAChRs has also been documented in the chick retina, where some types of $n A C h R$ appear at least two days before choline acetyltransferase is detected and about four days before the onset of synaptogenesis (Hamassaki-Britto et al. 1994).

\section{EFFECTS OF NICOTINIC AGONISTS AND ANTAGONISTS UPON NEURAL DEVELOPMENT IN VITRO}

Functional in vitro studies have been also conducted to assess the role of nAChRs during development. Primary cultures of neuron precursors or cultures of stable cell lineages have been analyzed to observe the relationship between $\mathrm{nAChR}$ expression and processes such as proliferation, cell survival and neurite outgrowth. The addition of the nicotinic agonist nicotine in PC12 cells and ciliary ganglion cultures produced a decreased rate of growth or even a retraction of neurites in both cases, which is in agreement with the popular idea of a growth inhibitory effect of nicotine in the developing central nervous system. This effect was reverted by application of $\alpha$-Bgt, which indicates that the effect is mediated through $\alpha$-Bgt-binding nAChRs (Chan and Quik 1993, Pugh and Berg 1994). Indeed, a developmental role of the nAChRs has been mainly suggested for the $\alpha$-Bgt-binding nAChR subtypes. These studies have suggested that neurite outgrowth regulation could be a result of an activation of the $\alpha$ Bgt-binding nAChR subtypes, which characteristically show a high calcium permeability. In addition to increasing the levels of intracellular calcium by fluxing the ion directly through the receptor channel, the activation of $\alpha$-Bgt-binding nAChR subtypes may activate voltage-gated calcium channels in vivo and then increment the calcium influx. Interestingly, a recent study has shown an opposite effect of nicotine. In this study, the addition of the nicotinic agonists to cultured olfactory bulb neurons produced significant increases in neuritic length, an effect that was abolished by treatment with $\alpha$-Bgt, indicating the involvement of $\alpha 7$-containing $\mathrm{nAChRs}$ in this process. This hypothesis was confirmed by binding assays with ${ }^{125} \mathrm{I}-\alpha$-Bgt (Coronas et al. 2000). These conflicting results could be related to different calcium concentrations in those cell culture preparations. It has been suggested that an optimal level of intracellular calcium is necessary for neuritic extension and outgrowth (Kater and Mills 1991) and it seems that these levels differ between neurons with spontaneous neurite outgrowth (PC12 cells and ciliary ganglion cells) and neurons with little neuritic extension under basal conditions (olfactory bulb neurons).

In the context of the above considerations, it is 


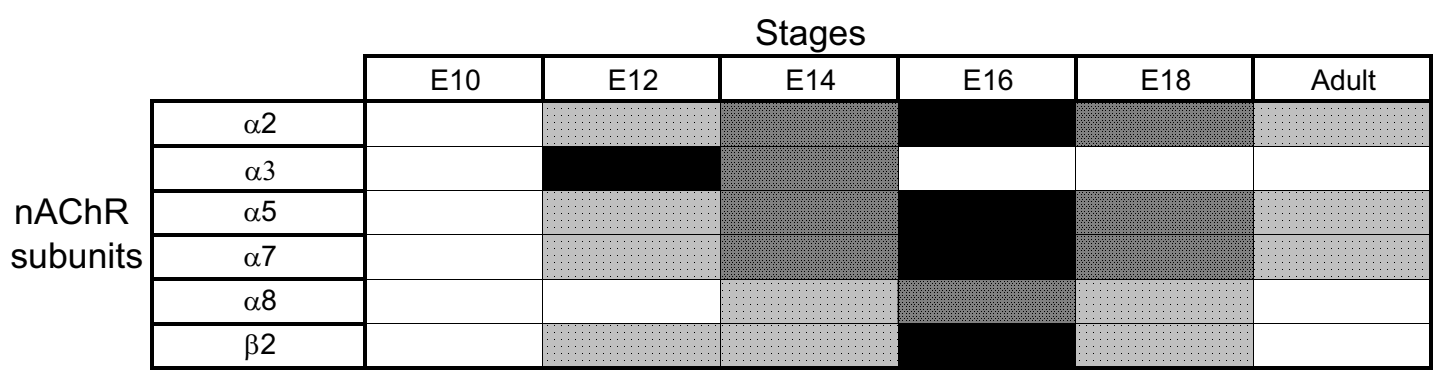
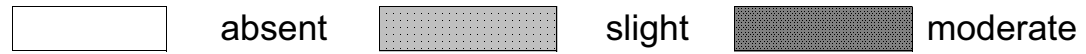

intense

Fig. 1 - Temporal evolution of immunoreactivity for nAChR subunits in Purkinje cells of the developing chick cerebellum. Note that the expression of most subunits tested peak around E16. The $\alpha 3$ subunit shows a peak of expression four days earlier.

also relevant that the treatment of primary cerebellar neuroblasts of rats with nicotine increased proliferation and cell survival (Opanashuk et al. 2001). Also, primary cell cultures from human fetal brain treated with nicotine showed an up-regulation of $\mathrm{nAChR}$ binding sites and increased expression of their transcripts (Hellstrom-Lindahl et al. 2001).

\section{EFFECTS OF NICOTINE UPON IN VIVO NEURAL DEVELOPMENT}

The effects of nicotine treatment upon the developing brain has also been assessed with in vivo studies. Nicotine treatment during the second postnatal week generated a disruption of the synaptic development of the rat auditory cortex (Aramakis et al. 2000). Also, rats treated with nicotine during the second postnatal week showed a persistent increase in the number of nAChR binding sites in the adult stage (Miao et al. 1998). These two studies indicate that the second postnatal week is critical in the developing rat brain and that nicotine treatment during this period could induce permanent effects on nAChRs. In addition, prenatal or embryonic nicotine exposure has been conducted to investigate its effects upon fetal development. These studies have investigated the morphological, functional, and behavioural changes that may be produced by early exposure to nicotine (e.g. Pennington et al. 1994).
Some studies have also addressed the question of nicotine-mediated effects upon the nAChR themselves and upon cholinoceptive neurons, which are presumptively the targets of nicotine in the brain. Prenatal nicotine exposure transiently increased the levels of $\alpha 4, \alpha 7$, and $\beta 2$ mRNA in hippocampus and cortex of postnatal rat brain (Shacka and Robinson 1998). On the other hand, the chronic infusion of nicotine in chick eggs did not change the density of (-)- $\left[{ }^{3} \mathrm{H}\right]$ nicotine-binding sites in the developing chick brain (Roll et al. 1993). We have found in our laboratory that the infusion of nicotine in chick eggs seems to produce a reduction of immunoreactivity for the $\alpha 2, \alpha 5, \alpha 8$, and $\beta 2 \mathrm{nAChR}$ subunits in perikarya and neuropil of specific regions of the chick embryonic brain, with an apparent disruption of the neuritic structure of neurons containing those subunits. In contrast, the infusion of $\alpha$-Bgt during specific stages of embryogenesis seemed to generate an increase of immunoreactivity for the $\alpha 8 \mathrm{nAChR}$ subunit. The dendritic arbors of the cholinoceptive neurons appeared to be more profusely ramified or at least much more visible when the cells were stained for the presence of that $\mathrm{nAChR}$ subunit (Fig. 2). This result suggests that early during development the nAChRs are responsive to nicotinic agonists and antagonists, and the development of nicotinic receptor-containing neurons may be regu- 
lated by blockade and activation of those nAChRs. The increased neuritic immunoreactivity for the $\alpha 8$ nAChR subunit and the enriched dendritic arbor observed after $\alpha$-Bgt infusion seem to agree with previous in vitro studies that have already implicated the $\alpha$-Bgt-sensitive nAChRs in morphogenetic processes (Chan and Quik 1993, Pugh and Berg 1994, Role and Berg 1996). The apparent facilitation of neurite development in ovo could be the result of an optimal calcium concentration obtained after the presumptive blockade of $\alpha 8$-containing receptors by $\alpha$-Bgt.

\section{CONCLUDING REMARKS}

The above data suggest that nAChRs, especially those of the $\alpha$-Bgt-type branch, may control the development of neural structures in which they are expressed. A possible mechanism for such a control could be the termination of axonal growth by presynaptic nAChRs that flux calcium. Acetylcholine released from growth cones might be responsible for the activation of those nAChRs. In addition, these receptors may influence the establishment of the dendritic morphology, which is suggested by both in vivo and in vitro experiments. Finally, it is noteworthy that these same mechanisms may operate during plastic remodeling in the adult brain (Dani et al. 2001). Taken together, the data reviewed here indicate that the cholinergic and other chemicallyspecific brain systems participate in neural development and plasticity, in addition to mediating neurotransmission in the adult brain.

\section{ACKNOWLEDGMENTS}

Work conducted in the authors' laboratory has been supported by FAPESP, CNPq, FINEP, and PRONEX/ MCT. A.S.T. was the recipient of a postdoctoral fellowship from FAPESP. Thanks are also due to Dr. Jon Lindstrom for his kind donation of monoclonal antibodies against nAChR subunits.
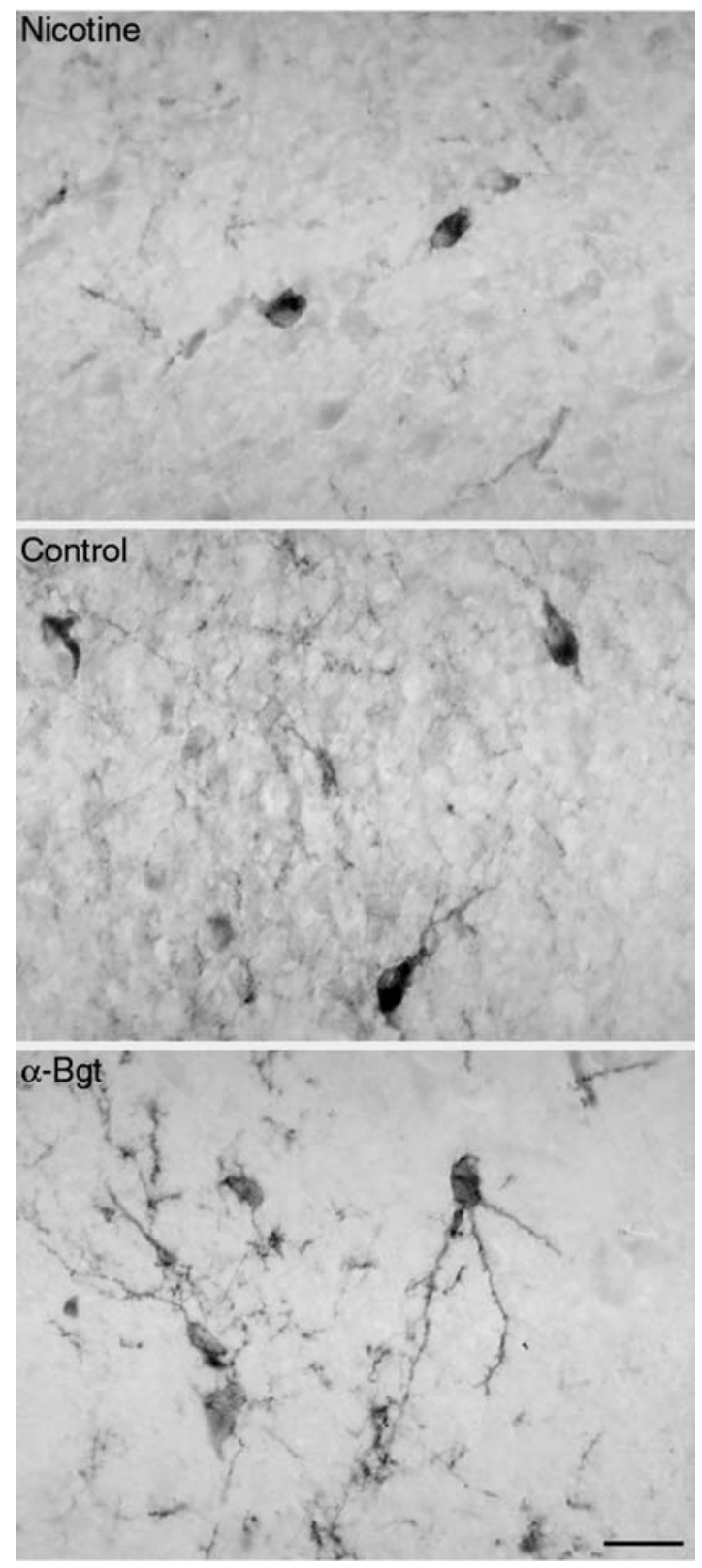

Fig. 2 - Effects of in ovo injections of nicotine and $\alpha$-Bgt upon $\alpha 8$-like immunoreactivity in neurons of the chick lateral mesencephalic reticular formation. Dendritic staining is much more evident after $\alpha$-Bgt. Nicotine, on the other hand, appears to reduce neuropil staining for $\alpha 8$. Control eggs were injected with either saline or distilled water. All embryos were treated from E15 through E17 with daily injections, and were sacrificed on E18. Scale bar: $25 \mu \mathrm{m}$. 


\section{RESUMO}

Na última década vários sistemas de neurotransmissores têm sido relacionados ao controle do desenvolvimento do sistema nervoso. Nesta revisão, nós discutimos as evidências de que os receptores nicotínicos da acetilcolina podem apresentar uma função incomum durante o desenvolvimento, que não deve estar relacionada com seu papel na neurotransmissão colinérgica no sistema nervoso de vertebrados. Dados sobre expressão temporal e estudos in vitro e in vivo com agonistas e antagonistas nicotínicos têm proporcionado apoio direto para a hipótese de uma função dos receptores nicotínicos no desenvolvimento neural, incluindo processos como crescimento neurítico e diferenciação. Um quadro similar tem sido obtido para outros sistemas de neurotransmissores e receptores, o que tem gerado uma nova visão dos processos neurais durante o desenvolvimento e a vida adulta.

Palavras-chave: acetilcolina, desenvolvimento, neurotransmissores, nicotina, receptores nicotínicos.

\section{REFERENCES}

Aramakis VB, Hsieh CY, Leslie FM and MetherATE R. 2000. A critical period for nicotine-induced disruption of synaptic development in rat auditory cortex. J Neurosci 20: 6106-6116.

Billinton A, Ige AO, Bolam JP, White JH, Marshall FH AND EMSON PC. 2001. Advances in the molecular understanding of GABA (B) receptors. Trends Neurosci 24: 277-282.

Boulter J, Connoly J, Deneris E, Goldman S, HeineMANN S AND PATRICK J. 1987. Functional expression of two neuronal nicotinic acetylcholine receptors from cDNA clones identifies a gene family. Proc Natl Acad Sci USA 48: 7763-7767.

Britto LRG, Hamassaki-Britto DE, Ferro ES, Keyser KT, Karten HJ and Lindstrom JM. 1992a. Neurons of the chick brain and retina expressing both $\alpha$-bungarotoxin-sensitive and $\alpha$-bungarotoxin-insensitive nicotinic acetylcholine receptors: an immunohistochemical analysis. Brain Res 590: 193-200.

Britto LRG, Keyser KT, Lindstrom JM AND KaRTEN HJ. 1992b. Immunohistochemical localization of nicotinic acetylcholine receptor subunits in the mesencephalon and diencephalon of the chick ( $\mathrm{Gal}$ lus gallus). J Comp Neurol 317: 325-340.

Chan J AND QUIK M. 1993. A role for the nicotinic $\alpha$ bungarotoxin receptor in neurite outgrowth in PC12 cells. Neurosci 56: 441-451.

Clarke PBS, Schwarts RD, Paul SM, Pert CB AND PeRT A. 1985. Nicotinic binding in rat brain: Autoradiographic comparison of $\left[{ }^{3} \mathrm{H}\right]$ acetylcholine, $\left[{ }^{3} \mathrm{H}\right]$ nicotine, and $\left[{ }^{125} \mathrm{I}\right]$ alpha-bungarotoxin. J Neurosci 5: 1307-1315.

Conroy WG And Berg DK. 1998. Nicotinic receptor subtypes in the developing chick brain: appearance of a species containing the $\alpha 4, \beta 2$, and $\alpha 5$ gene products. Mol Pharmacol 53: 392-401.

Constantine-Paton M, Cline HT and Debski E. 1990. Patterned activity, synaptic convergence, and the NMDA receptor in developing visual pathways. Annu Rev Neurosci 13: 129-154.

Contestabile A. 2000. Roles of NMDA receptor activity and nitric oxide production in brain development. Brain Res Rev 32: 476-509.

Coronas V, Durand M, Chabot JG, Jourdan F AND QUIRION R. 2000. Acetylcholine induces neuritic outgrowth in rat primary olfactory bulb cultures. Neurosci 98: 213-219.

DANi JA, Ji D And Zhou F-M. 2001. Synaptic plasticity and nicotine addiction. Neuron 31: 349-352.

Daubas P, Devillers-Thiéry A, Geoffroy B, Martinez S, Bessis A and Changeux J-P. 1990. Differential expression of the neuronal acetylcholine receptor $\alpha 2$ subunit gene during chick brain development. Neuron 5: 49-60.

Del Toro E, Juiz J, Peng X, Lindstrom J and Criado M. 1994. Immunocytochemical localization of the $\alpha 7$ subunit of the nicotinic acetylcholine receptor in the rat central nervous system. J Comp Neurol 349: 325-342.

Dineley-Miller K ANd Patrick J. 1992.Gene transcripts for the nicotinic acetylcholine receptor subunit $\beta 4$ are distributed in multiple areas of the rat central nervous system. Mol Brain Res 16: 339-344.

Duvoisin RM, Deneris ES, Patrick J And Heinemann S. 1989. The functional diversity of the neuronal nicotinic acetylcholine receptors is increased by a 
novel subunit: $\beta 4$. Neuron 3: 487-496.

Flanagan JG and Vanderhaegen P. 1998. The ephrins and eph receptors in neural development. Annu Rev Neurosci 21: 309-345.

Flores CM, Rogers SW, Pabreza LA, Wolfe BB AND Kellar KJ. 1992. A subtype of nicotinic cholinergic receptor in rat brain is composed of $\alpha 4$ and $\beta 2$ subunits and is up-regulated by chronic nicotine treatment. Mol Pharmacol 41: 31-37.

FRANCIS NJ AND LANDIS SC. 1999. Cellular and molecular determinants of sympathetic neuron development. Annu Rev Neurosci 22: 541-566.

Goldman D, Simmons D, Swanson LW, Patrick J And HeInEMANN S. 1986. Mapping of brain areas expressing RNA homologous to two different acetylcholine receptor $\alpha$-subunit cDNAs. Proc Natl Acad Sci USA 83: 4076-4080.

Goldman D, Deneris E, Luyten W, Kochhar A, Patrick J and Heinemann S. 1987. Members of a nicotinic acetylcholine receptor gene family are expressed in different regions of the mammalian central nervous system. Cell 48: 965-973.

Hamassaki-Britto DE, Brzozowska-Prechtl A, Karten HJ, Lindstrom JM and Keyser KT. 1991. Gaba-like immunoreactive cells containing nicotinic acetylcholine receptors in the chick retina. J Comp Neurol 313: 394-408.

Hamassaki-Britto DE, Gardino PF, HoKoç JN, Keyser KT, Karten HJ, Lindstrom JM AND BRITTO LR. 1994. Differential development of alpha - bungarotoxin - sensitive and alpha - bungarotoxin-insensitive nicotinic acetylcholine receptors in the chick retina. J Comp Neurol 347: 161-170.

Hatten ME. 1999. Central nervous system neuronal migration. Annu Rev Neurosci 22: 261-294.

Hellstrom-Lindahl E, Gorbounova O, Seiger A, Mousavi M AND Nordberg A. 1998. Regional distribution of nicotinic receptors during prenatal development of human brain and spinal cord. Dev Brain Res 108: 147-160.

Hellstrom-Lindahl E, Seiger A, Kuaeldgaard A AND Nordberg A. 2001. Nicotine-induced alterations in the expression of nicotinic receptors in primary cultures from human prenatal brain. Neurosci 105: 527-534.
HePP R AND LANGLEy K. 2001. SNAREs during development. Cell Tissue Res 305: 247-253.

HuAng EJ AND Reichardt LF. 2001. Neurotrophins: Roles in neuronal development and function. Annu Rev Neurosci 24: 677-736.

JOYNER AL. 1996. Engrailed, Wnt and Pax genes regulate midbrain-hindbrain development. Trends Genet 12: 15-20.

Kaneko WM, Britto LRG, Lindstrom J AND Karten HJ. 1998. Distribution of the $\alpha 7$ nicotinic acetylcholine receptor subunit in the developing chick cerebellum. Dev Brain Res 105: 141-145.

KATER SB AND Mills LR. 1991. Regulation of growth cone behavior by calcium. J Neurosci 11: 891-899.

Lankford KL, de Mello FG and Klein WL. 1988. D1-Type dopamine-receptors inhibit growth cone motility in cultured retina neurons-evidence that neurotransmitters act as morphogenic growth-regulators in the developing central nervous system. Proc Natl Acad Sci USA 85: 2839-2843.

Lindstrom J. 1998. Purification and cloning of nicotinic acetylcholine receptors. In Arneric SP and Brioni JD (Ed.), Neuronal nicotinic receptors: Pharmacology and therapeutic opportunities, Wiley-Liss Inc, p. 323.

LiPTON SA AND KATER SB. 1989. Neurotransmitter regulation of neuronal outgrowth, plasticity and survival. Trends Neurosci 12: 265-270.

LOHMANN THO, TORRÃo AS, BRITTO LRG, LINDSTROM J AND HAMASSAKI-BRitTo DE. 2000. A comparative non-radioactive in situ hybridization and immunohistochemical study of the distribution of $\alpha 7$ and $\alpha 8$ subunits of the nicotinic acetylcholine receptors in visual areas of the chick brain. Brain Res 852: 463469.

Maconochie M, Nonchev S, Morrison A and KrumLAUF R. 1996. Paralogous Hox genes: function and regulation. Annu Rev Genet 30: 529-556.

Matter JM, Matter-Sadzinski L And Ballivet M. 1990. Expression of neuronal nicotinic acetylcholine receptor genes in the developing visual system. EMBO J 9: 1021-1026.

Mendez-Otero R and Santiago MF. 2001. Functional role of a glycolipid in directional movements of neurons. An Acad Bras Cienc 73: 221-229. 
Miao H, Liu C, Bishop K, Gong ZH, Nordberg A and ZHANG X. 1998. Nicotine exposure during a critical period of development leads to persistent changes in nicotinic acetylcholine receptors of adult rat brain. $\mathrm{J}$ Neurochem 70: 752-762.

Morris BJ, Hicks AA, Wisden W, DARlinson MG, Hunt SP ANd BARnARd EA. 1990. Distinct regional expression of nicotinic acetylcholine receptor genes in chick brain. Mol Brain Res 7: 306-315.

Mueller BK. 1999. Growth cone guidance: first steps towards a deeper understanding. Annu Rev Neurosci 22: 351-388.

O'Leary DD and WiLKinson DG. 1999. Eph receptors and ephrins in neural development. Curr Opin Neurobiol 9: 65-73.

Opanashuk LA, Pauly JR and Hauser KF. 2001. Effect of nicotine on cerebellar granule neuron development. Eur J Neurosci 13: 48-56.

Pennington SN, SAndstrom LP, Shibley JR IA, Long SD, Beeker KR, Smith JR CP, Lee K, Jones TA, Cummings KM and Means LW. 1994. Biochemical changes, early brain growth supression and impaired detour learning in nicotine-treated chicks. Dev Brain Res 83: 181-189.

Pugh PC and Berg DK. 1994. Neuronal acetylcholine receptors that bind $\alpha$-bungarotoxin mediate neurite retraction in a calcium-dependent manner. J Neurosci 14: 889-896.

QuIK M. 1995. Growth related role for the nicotinic $\alpha$ bungarotoxin receptor. In Clarke $\mathrm{P}$ et al. (Ed.), Effects of nicotine on biological systems II, Birkhauser, p. $145-150$.

Rathouz MM, Vijayaraghavan S and Berg DK. 1996. Elevation of intracellular calcium levels in neurons by nicotinic acetylcholine receptors. Mol Neurobiol 12: 117-131.

ReICHARDT LF AND FARIÑAs I. 1997. Neurotrophic factors and their receptors: roles in neuronal development and function. In CowAN WM et al. (Ed.), Molecular and cellular approaches to neuronal development, New York: Oxford Univ Press, p. 220-263.

Role LW And Berg DK. 1996. Nicotinic receptors in the development and modulation of CNS synapses. Neuron 16: 1077-1085.

Roll RL, Timothy AJ, Benowitz NL and Morley
BJ. 1993. The chronic infusion of nicotine into the developing chick embryo does not alter the density of $(-)-\left[{ }^{3} \mathrm{H}\right]$ nicotine-binding sites or vestibular function. Brain Res 604: 260-265.

SARgent PB, Pike SH, NAdEl DB and Lindstrom JM. 1989. Nicotinic acetylcholine receptor-like molecules in the retina, retino-tectal pathway, and optic tectum of the frog. J Neurosci 9: 565-573.

Schacka JJ and Robinson SE. 1998. Exposure to prenatal nicotine transiently increases neuronal nicotinic receptor subunit alpha7, alpha4, and beta2 messenger RNAs in the postnatal rat brain. Neurosci 84 : 1151-1161.

Séguéla P, Wadiche J, Dineley-Miller K, Dani JA AND PATRICK JW. 1993. Molecular cloning, functional properties, and distribution of rat brain $\alpha 7$ : a nicotinic cation channel highly permeable to calcium. J Neurosci 13: 596-604.

Shatz CJ. 1990. Impulse activity and the patterning of connections during CNS development. Neuron 5: 745-756

Shatz CJ. 1997. Neurotrophins and visual system plasticity. In CowAN WM et al. (Ed.), Molecular and cellular approaches to neuronal development, New York: Oxford Univ Press, p. 509-524.

Simon DK, Prusky GT, O'Leary DDM and ConstanTINE-PATON M. 1992. N-methyl-D-aspartate receptor antagonists disrupt the formation of a mammalian neural map. Proc Natl Acad Sci USA 89: $10593-$ 10597.

SoRENSON EM AND ChiAPPINElli VA. 1992. Localization of ${ }^{3} \mathrm{H}$-nicotine, ${ }^{125} \mathrm{I}$-kappa-bungarotoxin, and 125 -alpha-bungarotoxin binding to nicotinic sites in the chicken forebrain and midbrain. J Comp Neurol 323: $1-12$.

Torrão AS, Lindstrom JM AND Britto LRG. 1997. Distribution of the $\alpha 2, \alpha 3$, and $\alpha 5$ nicotinic acetylcholine receptor subunits in the chick brain. Braz $\mathbf{J}$ Med Biol Res 30: 1209-1213.

Torrão AS, CARmona FMM, Lindstrom J AND BRITTO LRG. 2000. Expression of cholinergic system molecules during development of the chick nervous system. Dev Brain Res 124: 81-92.

Vijayaraghavan S, Pugh PC, Zhang ZW, Rathouz MM AND BERG DK. 1992. Nicotinic receptors that 
bind $\alpha$-bungarotoxin on neurons raise intracellular free $\mathrm{Ca}^{2+}$. Neuron 8: 353-362.

Wada E, Wada K, Boulter J, Deneris E, Heinemann S, PATrick J AND SwANSON LW. 1989. Distribution of alpha2, alpha3, alpha4 and beta2 neuronal nicotinic receptor subunit mRNAs in the central nervous system: a hybridization histochemical study in the rat. J Comp Neurol 284: 314-335.
Wada E, McKinnon D, Heinemann S, Patrick J and SWANSON LW. 1990. The distribution of mRNA encoded by a new member of the neuronal nicotinic acetylcholine receptor gene family $(\alpha 5)$ in the rat central nervous system. Brain Res 526: 45-53.

Zoli M, Le Novère N, Hill Jr. JA ANd Changeux JP. 1995. Developmental regulation of nicotinic ACh receptor subunit mRNAs in the rat central and peripheral nervous systems. J Neurosci 15: 1912-1939. 